\title{
Identification of appropriate reference genes for local immune-related studies in Morada Nova sheep infected with Haemonchus contortus
}

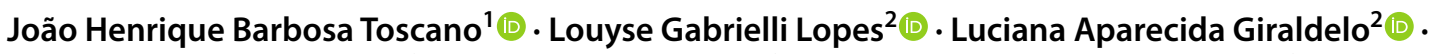 \\ Matheus Henrique da Silva ${ }^{2}$ (1) . Cintia Hiromi Okino ${ }^{3}$ (1) Ana Carolina de Souza Chagas ${ }^{3}$ (I)
}

Received: 2 July 2018 / Accepted: 24 July 2018 / Published online: 1 August 2018

(c) Springer Nature B.V. 2018

\begin{abstract}
Due to the great economic impact of Haemonchus contortus on sheep farming, there is an increasing number of studies addressing host resistance against this nematode, including identification of directly related immune mechanisms. In this context, relative gene expression by RT-qPCR have been largely used, due to its rapidity, high sensitivity, specificity, and reproducibility. Although, appropriate reference gene selection is crucial for accurate interpretation of results. In this study, five reference genes (GAPDH, G6PDH, YWHAZ, ACTB, and B2M) were tested for expression stability in abomasum (fundic and pyloric regions) and abomasal lymph nodes of Morada Nova sheep classified as resistant $(n=5)$ or susceptible $(n=5)$ to $H$. contortus infection in a flock of 151 animals. GAPDH combined with $Y W H A Z$ were selected as reference genes for abomasal fundic region and abomasal lymph nodes, whereas YWHAZ was the most stable gene for abomasal pyloric region. These genes presented the lowest intra- and inter-group variations and, consequently, highest stability. In contrast, expression of $G 6 P D H$ was the least stable in all tissues. The impact of reference gene selection was demonstrated by relative quantification of a pro-inflammatory cytokine $(T N F \alpha)$ in abomasal fundic region. Significant differences in TNF $\alpha$ expression levels between resistant and susceptible groups were only observed when the most stable genes (GAPDH combined with YWHAZ) or $G A P D H$ were used as reference genes, whereas no significant differences were observed when other tested reference genes were used. It was demonstrated that normalization of expression data using inappropriate reference genes may significantly influence interpretation results.
\end{abstract}

Keywords Reference gene $\cdot$ RT-qPCR $\cdot$ Haemonchus contortus $\cdot$ Host resistance $\cdot$ Morada Nova breed $\cdot$ Sheep

\section{Introduction}

Gastrointestinal nematode (GIN) infections are the main cause of economic losses to ovine farmers worldwide, especially in tropical countries. In Brazil, Haemonchus contortus is considered the most pathogenic and, consequently, the most economically relevant [1-3]. In view of increasing

João Henrique Barbosa Toscano

joaoh.toscano@gmail.com

1 Universidade Estadual Paulista Júlio de Mesquita Filho, Via de Acesso Prof. Paulo Donato Castellane, s/n, Jaboticabal, SP 14884-900, Brazil

2 Centro Universitário Central Paulista, Rua Miguel Petroni, 5111, São Carlos, SP 13563-470, Brazil

3 Embrapa Pecuária Sudeste, Rodovia Washington Luiz, Km 234 s/n, Fazenda Canchim, PO Box 339, São Carlos, SP 13560-970, Brazil multiple anthelmintic resistance $[1,4,5]$, alternative control methods, in which selection of resistant lineages may be considered an excellent alternative, are required. Regarding Brazilian sheep breeds, the Morada Nova, originated from northeast of the country, presents several positive features, such as tropical climate adaptation, sexual precocity, high prolificacy, excellent skin quality [6], and increased resistance to GIN infections [7]. Recent studies have shown slighter impact induced by GIN infections over this sheep breed compared with other breeds such as Dorper, Texel, Ile de France, and Santa Inês. Even in more critical categories such as females in pre and postpartum period, in which immunosuppression from nutritional and endocrine origin leads to increased infection rates, Morada Nova ewes presented lower FEC and higher PCV than the other breeds $[8,9]$.

Aiming to better understand the mechanisms involved in host resistance against GIN infections, investigation of 
genetic, physiological and immune-mediated mechanisms is essential. In this context, relative gene expression studies by RT-qPCR have been increasingly used [10-13], due to its rapidity, high sensitivity, specificity, and reproducibility $[14,15]$. Nevertheless, such method is used for confirmation of the results found in more comprehensive transcriptomic studies, such as RNA-seq $[11,16]$.

However, a range of variables, either alone or cumulatively, need to be considered in RT-qPCR studies, such as the amount and quality of RNA samples, efficiency of reverse transcription (enzymatic activity and primers used), presence of reaction inhibitors, efficiency of primers used in qPCR, and differences in cell numbers between different samples [14, 17-20]. For normalization of such variables, the most commonly applied method is the use of one or more reference genes, in which the expression levels must be stable in the target tissue, considering the different treatments, groups, and other experimental conditions [14, 21]. In this context, selection of a suitable reference gene is essential. The widely used ribosomal RNA (18S or $28 \mathrm{~S}$ rRNA), for example, is not the most appropriate gene mainly because its expression is much higher and its degradation inferior to those of the target mRNA, the rRNA:mRNA ratio is highly variable between different samples, and its transcription pathway is independent of that of mRNA [21-23]. Furthermore, the selection of a reference gene based only on a literature search is equally inadequate, because the expression levels of several constitutive genes, such as GAPDH and ACTB, is known to vary considerably in the same tissue when tested under different experimental conditions [24-26]. Thus, previous reference gene validation is essential for each tissue and study, based on a set of candidate genes.

To validate reference gene candidates, regarding their stability, several computer programs are available, among which the most used are the Microsoft excel add-ins Bestkeeper [27] and Normfinder [28], which use the Cq as inputs (with or without log transformation), and account for differences in primer binding efficiency. Recently, a free online platform has been made available, RefFinder (http://leonx ie.esy.es/RefFinder/), which combines the geometric means of the stability values calculated by the main algorithms currently available (Bestkeeper, Normfinder, GeNorm, and comparative $\mathrm{Cq}$ method), creating a comprehensive ranking.

The present study aimed to evaluate the stability of five reference gene candidates (GAPDH, G6PDH, YWHAZ, $A C T B$, and $B 2 M$ ) in abomasum (fundic and pyloric regions) and abomasal lymph nodes of Morada Nova lambs experimentally infected with $H$. contortus from different resistance phenotypes (resistant and susceptible), using three different software (Bestkeeper, Normfinder, and RefFinder). Moreover, efficacy of the most stable reference gene on normalization of $T N F \alpha$ transcripts was also compared with those of the other selecting candidates.

\section{Materials and methods}

\section{Animal phenotyping and sample collection}

151 Morada Nova lambs ( 79 males and 72 females), born between April and May 2017, were weaned at an age of approximately 100 days. Faecal examinations showed that these animals presented natural GIN infection, with an average of $8179 \pm 10,678$ eggs per gram of faeces (EPG), with predominance of Haemonchus sp. (95.7\%), followed by Cooperia sp. (2.53\%) and Trichostrongylus sp. (1.77\%). In small quantities, Strongyloides sp. and Moniezia sp. eggs and Eimeria sp. oocysts were found in the faeces of some animals. The lambs were kept in four paddocks, separated by sex (males and females) and month of birth (April and May). These four paddocks were kept free from animal grazing 4 months before the beginning of the study and had the pasture was cut close to the soil every 15 days to reduce GIN contamination.

Immediately after weaning, the lambs were treated with $2.5 \%$ monepantel (Zolvix ${ }^{\circledR}$, Novartis) at $2.5 \mathrm{mg} / \mathrm{kg}$ dose to eliminate natural GIN infection, confirmed by two faecal egg counts (FEC), at days 7 and 14 post-deworming. After 15 days, they were experimentally infected with $4 \times 10^{3} \mathrm{H}$. contortus $\mathrm{L}_{3}$ (Echevarria 1991 isolate)—day zero, according to the recommendations of the World Association for the Advancement of Veterinary Parasitology [29]. Fecal samples were collected individually for FEC at days zero, 21, 28, 35, and 42 , followed by a second monepantel treatment. 15 days later, the animals were subjected to a second parasitic challenge according to the previous scheme. For packed cell volume (PCV) determination, blood samples were collected on days zero, 14, 28, and 42 of each challenge. Based on the averages FEC (excluding post-deworming values) and PCV, from the weaning to the end of the second parasitic challenge, the animals were phenotypically classified according to their resistance to $H$. contortus infection. The ten lambs classified as extreme resistance phenotypes, five most resistant (lowest FEC and highest PCV) and five most susceptible (highest FEC and lowest PCV) were submitted to a third monepantel treatment and parasitic challenge with $4 \times 10^{3} \mathrm{H}$. contortus $\mathrm{L}_{3} .7$ days later, they were slaughtered and tissue samples from abomasum (fundic and pyloric regions) and abomasal lymph nodes were collected, immediately frozen in liquid nitrogen $\left(-180^{\circ} \mathrm{C}\right)$, and stored at $-80^{\circ} \mathrm{C}$ for total RNA extraction.

\section{RNA extraction and CDNA synthesis}

Total RNA was extracted from $0.1 \mathrm{~g}$ (abomasum) or $0.2 \mathrm{~g}$ (abomasal lymph nodes) of the tissue samples by organic 
extraction using QIAzol® Lysis Reagent (Qiagen, Cat. 79306) and TissueRupter tissue homogenizer (Qiagen, Cat. 9002710), followed by purification using RNeasy Mini Kit (Qiagen, Cat. 74106).

Quantification and purity of the extracted RNA were estimated by $260 \mathrm{~nm}$ ultraviolet absorbance and readings at 260/280 nm, respectively, by spectrophotometry (NanoDrop 2000, Thermo Scientific). RNA quality was confirmed by $1 \%$ agarose gel electrophoresis.

The complementary DNA (cDNA) were synthetized from $1500 \mathrm{ng}$ of total RNA, using the High-Capacity cDNA Reverse Transcription Kit (Applied BiosystemsTM, Cat. 4368814) and OligodT primers (Sigma), according to manufacturers' instructions, in T100TM Thermal Cycler (Bio-Rad).

\section{Reference genes and target gene selection}

Selection of the reference gene candidates was based on those commonly used for RT-qPCR studies in different ruminant tissues [30-34]. Five reference gene candidates with different cellular functions were selected: glyceraldehyde 3-phosphate dehydrogenase $(G A P D H)$ and glucose 6-phosphate dehydrogenase ( $G 6 P D H)$, enzymes associated with carbohydrate metabolism; tyrosine 3-monoxygenase ( $Y W H A Z$ ), involved in intercellular signal transduction; actin beta $(A C T B)$, cytoskeletal structural protein; beta-2 microglobulin $(B 2 M)$, a component of histocompatibility complex (MHC) class I beta chain. Tumor necrosis factor alpha $(T N F \alpha)$, a pro-inflammatory cytokine previously associated with enhanced susceptibility to GIN infections in sheep [35], was selected as target gene to measure the impact of reference gene choice on data normalization.

All oligonucleotides were designed using Primer3 (http:// frodo.wi.mit.edu) software, spanning exons according to gene sequences from Ensembl (http://ensembl.org), and mRNA sequences deposited in GenBank. Primer sequences were analyzed by Netprimer (https://www.premierbiosoft. com/netprimer) and Oligoanalyzer (https://www.idtdna.com/ calc/analyzer) computer programs in order to evaluate formation of possible secondary structures. To verify specificity, the expected amplicon sequences were aligned with those deposited in the international databases through the Basic Local Alignment Search Tool (BLAST) program.

\section{Real time quantitative PCR (qPCR)}

The reactions were conducted in 7500 Real-Time PCR System Thermal Cycler (Applied Biosystems) using SYBR Green I DNA intercalating dye, MicroAmp® Optical 96-Well Reaction Plates (Applied Biosystems, Cat. N8010560) and MicroAmp ${ }^{\circledR}$ Optical Adhesive Films (Applied Biosystems, Cat. 4311971). The qPCR reactions contained $20 \mathrm{ng}$ of cDNA, $7.5 \mu \mathrm{L}$ of $2 \times$ Quantifast SYBR Green PCR Master Mix (Qiagen, Cat. 204056), and 0.3 $\mu \mathrm{M}$ of each primer in a final volume of $15 \mu \mathrm{L}$. Amplification included a pre-incubation step at $95{ }^{\circ} \mathrm{C}$ for $5 \mathrm{~min}$, followed by 40 cycles at $95{ }^{\circ} \mathrm{C}$ for $15 \mathrm{~s}$ and at $60^{\circ} \mathrm{C}$ for $35 \mathrm{~s}$. After amplification, a melting curve analysis was performed by raising the incubation temperature from 65 to $95{ }^{\circ} \mathrm{C}$ in $0.5{ }^{\circ} \mathrm{C}$ increments. All samples were tested in duplicate and, for each gene, in each qPCR run, a no template control (NTC) was included. The threshold values were set to 0.02 for all genes.

Specificity of the amplified products was confirmed by visualization of expected amplicon size in $2.5 \%$ agarose gel electrophoresis. The efficiencies of each specific RT-qPCR were calculated using fivefold serial dilutions of cDNA.

\section{Stability test and statistical analysis}

Stability of the five reference gene candidates for each evaluated tissue (abomasal fundic and pyloric regions and abomasal lymph nodes) was tested using three computational software suites: Bestkeeper, Normfinder, and RefFinder.

$T N F \alpha$ relative gene expression was normalized by different reference gene candidates [36]. For each evaluated tissue, the sample presenting the lowest expression level (highest $\mathrm{Cq}$ value) was used as calibrator.

The Cq means of the reference gene candidates in the different tissues were analyzed by the Kruskal-Walis test, followed by the Dunn's multiple comparison test. The comparisons of relative changes in TNF $\alpha$ gene expression between the resistant and susceptible groups normalized by different reference gene candidates were performed using the Mann-Whitney $U$ test. All analyses were processed using GraphPad Prism 7.0 for MacOS X, and the probability level for significance was set at $\mathrm{P}<0.05$.

\section{Results}

\section{Specificity and efficiency of qPCR assays}

Specificity of the developed qPCR assays was confirmed by visualization of unique fragment presenting expected size in agarose gel electrophoresis. In addition, only one peak in the dissociation curve was observed (Fig. 1). Primer dimers were verified in NTC for $A C T B, B 2 M$ and $T N F \alpha$ qPCR assays, but these unspecific products presented markedly lower melting temperature compared with those observed in specific products. qPCR efficiency values ranged from 92.31 to $101.64 \%$, and the correlation coefficient $\left(\mathrm{r}^{2}\right)$ ranged from 0.983 to 0.999 (Table 1). 

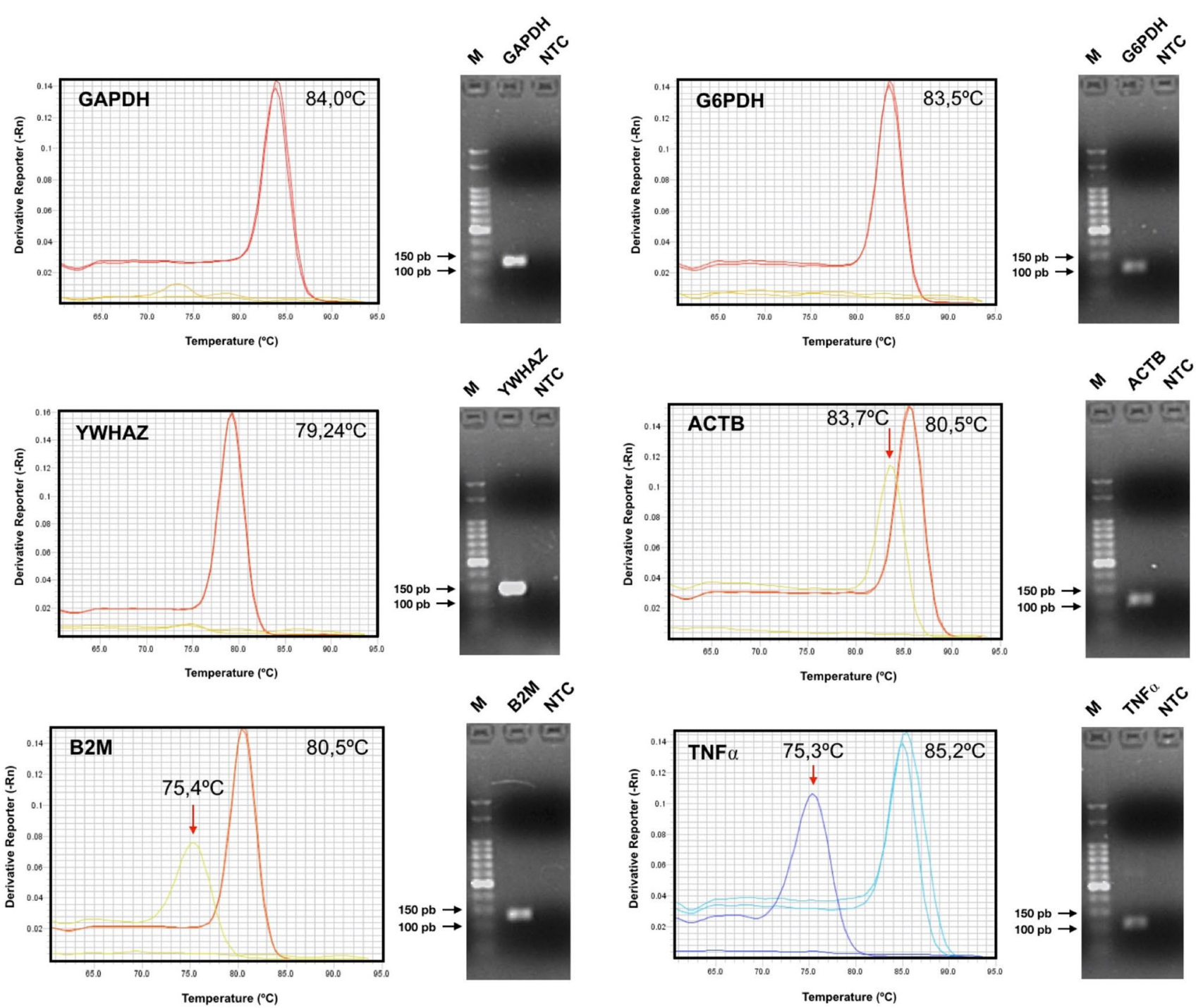

Fig. 1 Dissociation curves (including melting temperatures) and 2.5\% agarose gel electrophoresis of the amplification products of the five reference gene candidates and the target-gene $T N F \alpha$. Arrows indicate

primer dimers observed in NTC. (M) 50 bp DNA Ladder (Ludwig Biotec); NTC no template control

Table 1 Sequence of the primers designed for amplification of the five reference gene candidates and the target-gene TNF $\alpha$

\begin{tabular}{|c|c|c|c|c|c|c|c|}
\hline Gene & Accession number & Primer sequences $\left(5^{\prime}-3^{\prime}\right)$ & $\begin{array}{l}\text { Product } \\
\text { size (bp) }\end{array}$ & Exon boundary & Efficiency (\%) & $\mathrm{R}^{2}$ & Slope \\
\hline$G A P D H$ & NM_001190390.1 & $\begin{array}{l}\text { F: CAAGCTCATTTCCTGGTACGAC } \\
\text { R: TCTCTCTTCCTCTCGTGCTCCT }\end{array}$ & 131 & $10 / 11$ & 99.136 & 0.999 & -3.343 \\
\hline G6PDH & NM_001093780.1 & $\begin{array}{l}\text { F: TGAGCCCTTCTTCAAAGCTACC } \\
\text { R: GCTCGTAGGAGGCAGTGTCAT }\end{array}$ & 107 & $4 / 5$ & 92.310 & 0.994 & -3.524 \\
\hline$Y W H A Z$ & NM_001267887.1 & $\begin{array}{l}\text { F: CTGAGAAAGCCTGCTCTCTTGC } \\
\text { R: GGTATCCGATGTCCACAATGTC }\end{array}$ & 143 & $5 / 6$ & 102.344 & 0.999 & -3.267 \\
\hline$A C T B$ & NM_001009784 & $\begin{array}{l}\text { F:CTCCCTGGAGAAGAGCTACGAG } \\
\text { R: GATTCCATGCCCAGGAAGG }\end{array}$ & 111 & $4 / 5$ & 101.423 & 0.999 & -3.288 \\
\hline$B 2 M$ & NM_001009284 & $\begin{array}{l}\text { F: CAGCGTATTCCAGAGGTCCAG } \\
\text { R: CCCGTTCTTCAGCAAATCG }\end{array}$ & 126 & $1 / 2$ & 101.640 & 0.999 & -3.283 \\
\hline$T N F \alpha$ & NM_001024860 & $\begin{array}{l}\text { F: CTCAGGTCATCTTCTCAAGCCT } \\
\text { R: GAGGGCATTGGCATACGAG }\end{array}$ & 108 & $2 / 3$ & 94.086 & 0.983 & -3.472 \\
\hline
\end{tabular}




\section{Expression profiles of reference gene candidates in different tissues}

$A C T B$ and $B 2 M$ were the most expressed genes in all evaluated tissues, whereas G6PDH presented the lowest expression (Table 2; Fig. 2). Regarding the reference gene expression levels in different tissues, abomasal fundic region presented the lowest variation on the expression of the five reference genes, followed by abomasal pyloric region, whereas the highest variations were found in the abomasal lymph nodes.

Regarding the comparisons of reference gene expression levels between groups (resistant and susceptible to $H$. contortus infection), significant difference $(\mathrm{P}<0.05)$ was observed for $G A P D H$ in abomasal pyloric region, whereas no significant differences were found for the other genes and/or tissues.

\section{Reference gene stability test}

Bestkeeper and Normfinder analyses indicated $Y W H A Z$ as the most stable gene for abomasal fundic region; in addition, the combination of GAPDH and YWHAZ (geometric men of $\mathrm{Cq}$ values) were also indicated by the Normfinder software. RefFinder analysis results were partially different, where $G A P D H$ was ranked as the most stable gene, followed by $Y W H A Z$. However, all three algorithms indicated G6PDH as the least stable.

Analysis by the three programs indicated $Y W H A Z$ as the most stable gene for abomasal pyloric region. In addition, $G A P D H$ and $G 6 P D H$ were listed as the least stable by the three programs in this tissue.

Regarding evaluation in abomasal lymph nodes, $A C T B$ was listed as the most stable gene by Bestkeeper and RefFinder analyses. However, a high coefficient of variation of $A C T B \mathrm{Cq}$ values $(\mathrm{CV}=14.07 \%)$ between biological replicates was observed in this tissue. GAPDH ranged between second (Normfinder and RefFinder) and third (Bestkeeper) most stable gene, but a high coefficient of variation was observed in its expression levels $(\mathrm{CV}=8.42 \%)$. In contrast, $Y W H A Z$ was listed as the second (Bestkeeper) or third (Normfinder and RefFinder) most stable gene, and showed a low coefficient of variation of $\mathrm{Cq}$ values $(\mathrm{CV}=5.56 \%)$ (Fig. 3).

\section{Inaccurate gene expression results related to erroneous reference gene selection}

No significant differences were observed between the resistant and susceptible groups regarding $T N F \alpha$ gene expression (relative expression normalized by either one of the
Table 2 Means \pm standard deviations and coefficient of variation $(\mathrm{CV})$ of $\mathrm{Cq}$ values from the five reference gene candidates for the abomasal fundic (AF) and pyloric (AP) regions and abomasal lymph nodes (AL)

\begin{tabular}{|c|c|c|c|c|c|c|}
\hline \multirow[t]{2}{*}{ Gene } & \multicolumn{2}{|l|}{$\mathrm{AF}$} & \multicolumn{2}{|l|}{ AP } & \multicolumn{2}{|l|}{$\mathrm{AL}$} \\
\hline & Cq mean & CV (\%) & Cq mean & $\mathrm{CV}(\%)$ & Cq mean & CV (\%) \\
\hline GAPDH & $18.53 \pm 0.45$ & 2.45 & $17.67 \pm 0.90$ & 5.12 & $19.08 \pm 1.61$ & 8.42 \\
\hline$G 6 P D H$ & $23.66 \pm 0.41$ & 2.15 & $25.15 \pm 0.83$ & 3.31 & $29.43 \pm 3.89$ & 13.22 \\
\hline$Y W H A Z$ & $20.53 \pm 0.47$ & 2.27 & $20.16 \pm 0.64$ & 3.18 & $20.84 \pm 1.16$ & 5.56 \\
\hline ACTB & $17.33 \pm 0.45$ & 2.91 & $16.47 \pm 0.90$ & 5.48 & $19.02 \pm 2.68$ & 14.07 \\
\hline$B 2 M$ & $16.07 \pm 0.72$ & 4.51 & $15.87 \pm 0.87$ & 5.48 & $15.56 \pm 0.78$ & 5.04 \\
\hline
\end{tabular}

Resistant IIII Susceptible
Fundic Region

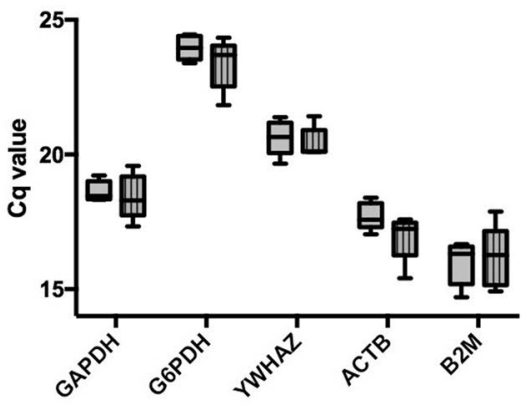

Pyloric Region

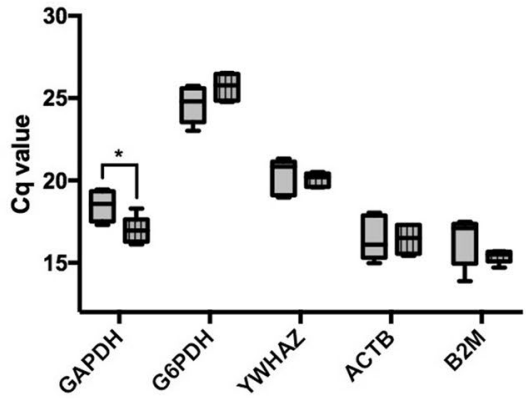

Abomasal Lymph Nodes

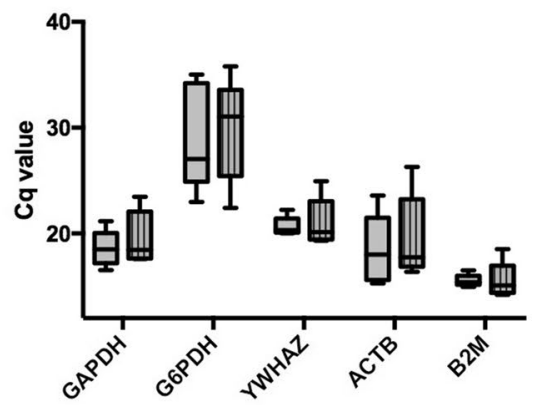

Fig. 2 Distribution of expression levels, based on Cq values, from each of the five reference gene candidates, separated by group (resistant and susceptible) in the three tissues evaluated. Asterisks indicate significant difference $(* \mathrm{P}<0.05)$ by the Mann-Whitney $U$ test 
(a)

Bestkeeper

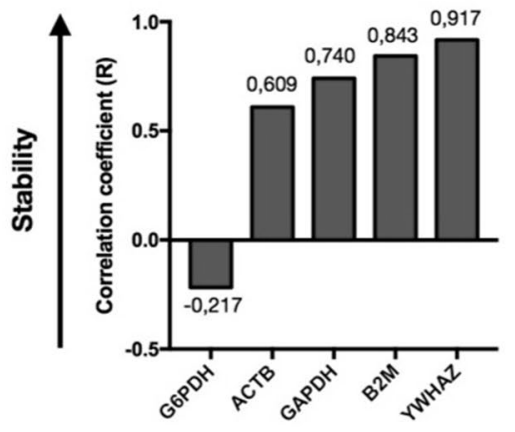

(b)

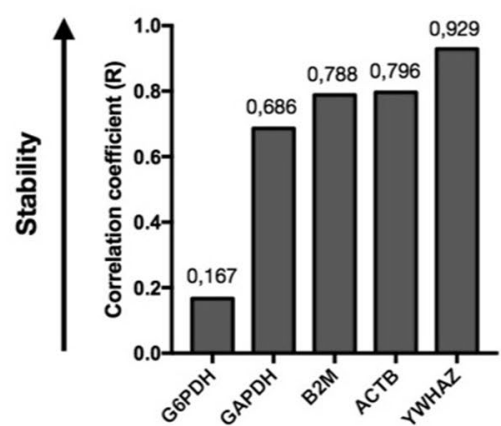

(c)

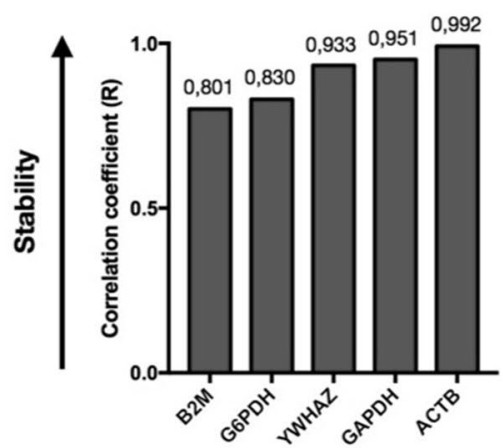

Normfinder

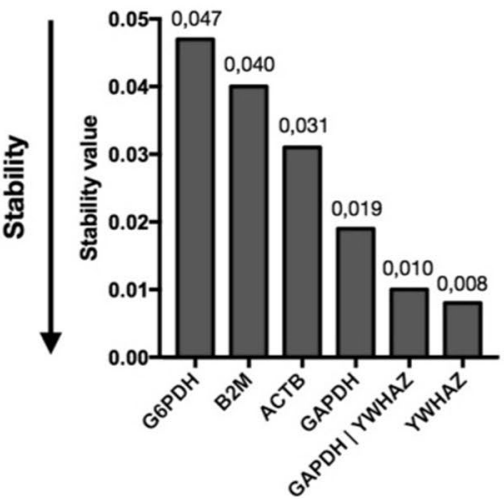

Normfinder

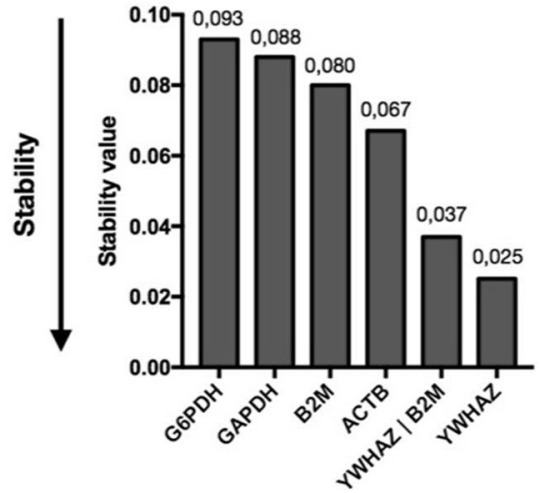

Normfinder

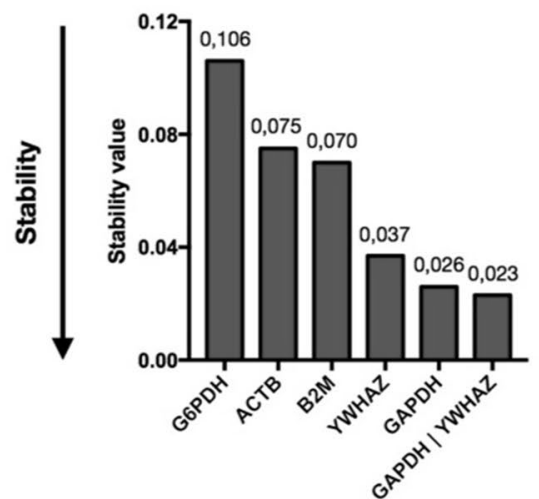

RefFinder

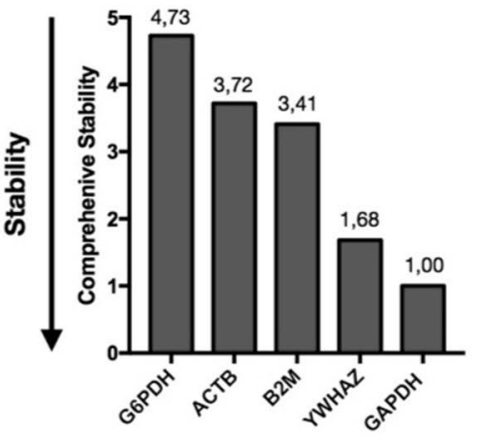

RefFinder

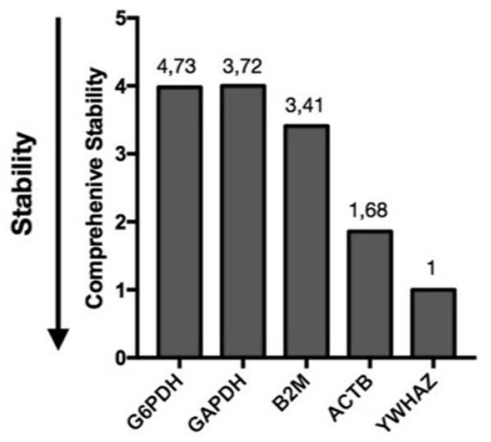

RefFinder

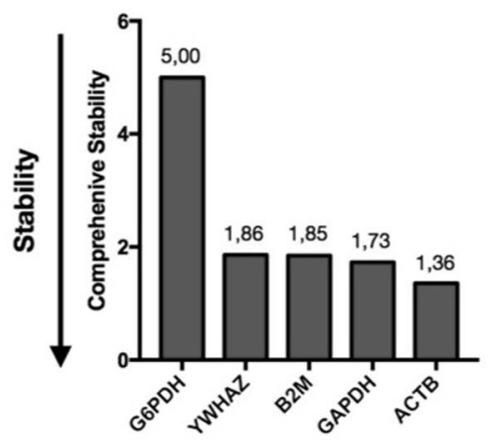

Fig. 3 Stability test results as calculated by three computer programs (Bestkeeper, Normfinder, and RefFinder), for abomasal fundic region (a), abomasal pyloric region (b), and abomasal lymph nodes (c) 
evaluated reference genes) in both abomasal pyloric region and abomasal lymph nodes.

In abomasal fundic region, $T N F \alpha$ transcript levels were significantly higher in susceptible compared with resistant animals, when relative expression was normalized by GAPDH $(\mathrm{P}=0.0159)$ or using $G A P D H$ combined with $Y W H A Z(\mathrm{P}=0.0317)$. However, no significant differences in these transcript levels were observed using G6PDH, ACTB, or $B 2 M$ as reference genes (Fig. 4).

\section{Discussion}

An ideal reference gene should be stably and constantly expressed in different cells and tissues, regardless of the physiological state and experimental conditions [21, 28]. $G A P D H$ and $A C T B$ have been frequently used as reference genes in the literature and are considered universal by some authors [18, 37]. However, such genes did not exhibit the highest expression stability in the present experimental conditions, and therefore were not reliable as reference genes.
Although the combination between GAPDH and $Y W H A Z$ genes presented high stability levels for both abomasal fundic region and lymph nodes, GAPDH gene presented poor stability levels in pyloric region by all algorithms evaluated, and this gene was differentially expressed between resistant and susceptible groups. In contrast, $A C T B$ presented high stability levels by RefFinder and Bestkeeper software analyses in the abomasal lymph nodes, but due to the high coefficient of variation observed for this gene, its potential as a suitable reference gene for the present experiment seems to be low. The results are in agreement with those of previous experiments, in which neither GAPDH nor $A C T B$ was listed as appropriate reference genes in studies addressing GIN resistance in ruminants $[10,31,37,38]$.

In the present study, $Y W H A Z$ gene was indicated as one of the most stable genes, alone or combined with GAPDH. $Y W H A Z$ was used as reference gene in relative expression studies using lymph nodes from sheep considered resistant or susceptible to Teladorsagia circumcinta [39-41]. In addition, GAPDH gene was previously selected as reference gene in a similar study using ovine abomasum from
Normalized to GAPDH

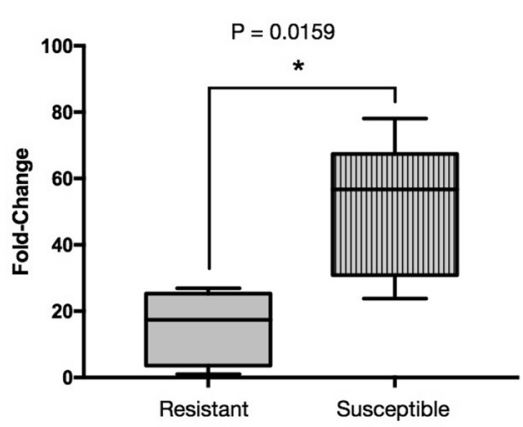

Normalized to ACTB

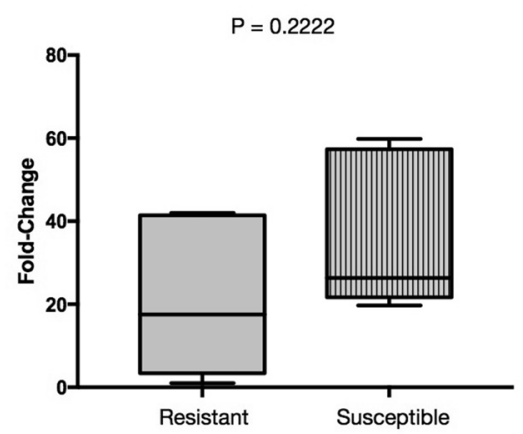

Normalized to G6PDH

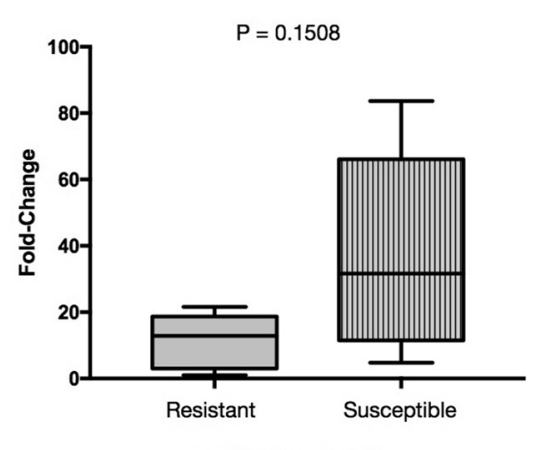

LEAST stable

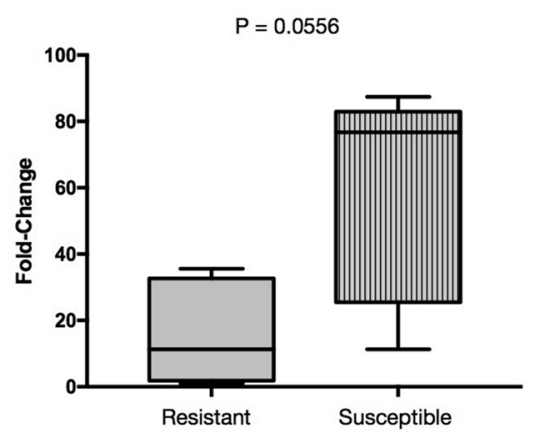

Normalized to YWHAZ

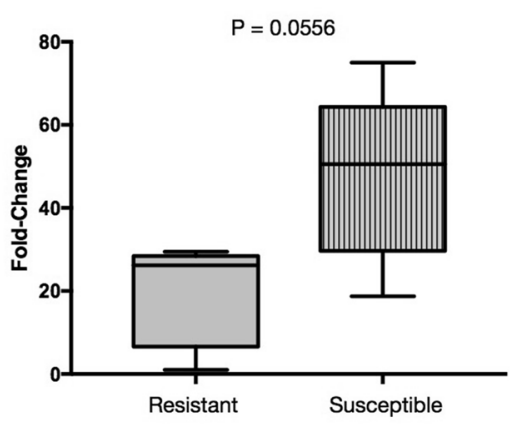

Normalized to GAPDH | YWHAZ

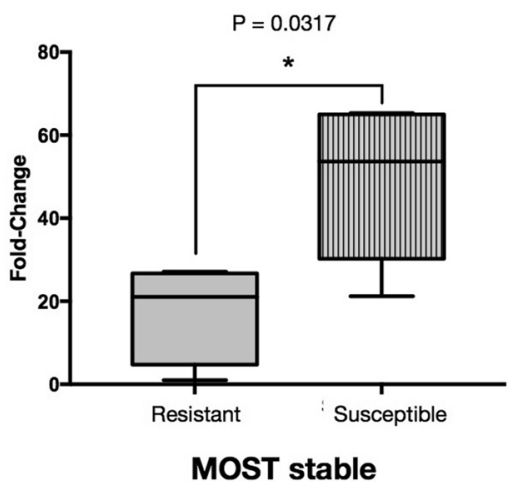

Fig. 4 Effect of normalization with the different reference gene candidates on $T N F \alpha$ expression levels in abomasal fundic region of Morada Nova lambs resistant and susceptible to $H$. contortus infection. Asterisks indicate significant difference $(* \mathrm{P}<0.05)$ by the Mann-Whitney $U$ test 
animals resistant or susceptible to GIN [12]. Nevertheless, from all reference gene candidates tested in these studies, only GAPDH and $A C T B$ were in common compared with the present study. Few studies have included $Y W H A Z$ as a candidate reference gene for stability testing in studies involving helminthic infections. However, the high stability level of this gene obtained in this and other studies [32, 42], considering different tissues and experimental conditions, indicates it as a good reference gene candidate. In contrast, G6PDH presented the lowest stability level in the present experimental conditions in all three tissues evaluated. In addition, it presented the lowest expression values compared with those of the other reference candidates. Although there are no studies using $G 6 P D H$ as reference gene for experiments related to host resistance against nematode parasites, this gene was considered highly stable in sheep neutrophils [32] and nervous tissue [30], but presented low stability levels in sheep bone tissue [43]. This wide variation of results regarding selection of appropriate reference gene in gene expression studies highlights the absence of a universal gene and reinforces the importance of previous validation.

Regarding the different programs used to perform stability testing in the present study, each one has a differential algorithm. Bestkeeper [27] performs consecutive pairwise correlation analyses (Pearson's correlation test) between the different candidate genes and between them and the geometric mean of all the other genes. Although several studies have used only the correlation coefficient (r) value to rank the stability of the candidate genes, the coefficient of variation of $\mathrm{Cq}$ values between biological replicates within a tissue may constitute an important criterion, as evidenced in the present study, in which high coefficient of variation was observed for $A C T B$ gene in the abomasal lymph nodes, with this gene indicated as the one with the highest stability by the Bestkeeper and RefFinder software programs. Normfinder algorithm considers variations unrestricted to different samples, but includes differences between and within experimental groups. Such variations are very important factors to be considered in reference gene validation, as demonstrated in the present study, where significant difference $(\mathrm{P}<0.05)$ between resistant and susceptible groups was observed for GAPDH Cq values in the abomasal pyloric region, which corroborated the findings of other studies [20, $32,44]$. Another advantage of this program is the suggestion of combinations of reference genes instead using only one. RefFinder integrates the main currently available computational programs (geNorm, Normfinder, Bestkeeper, and comparative delta $\mathrm{Cq}$ method) in a single comprehensive ranking, but presents the disadvantage of inputting only raw $\mathrm{Cq}$ values, wherein the efficiency correction was not available, and consequently could lead to inaccurate results, especially by using qPCR assays with low efficiency values, such as for $G 6 P D H$ in the present study $(\mathrm{E}=92.31 \%)$.
Although some inconsistencies have been observed regarding the most appropriate reference gene indicated by the different computational programs tested, all of them have indicated the same genes as less stable for each tissue, corroborating the results of previous studies [15, 32]. Therefore, considering the advantages and disadvantages of each computational program, the use of more than one algorithm to better rank the stability of reference gene candidates is highly recommended.

Finally, the different results obtained for $T N F \alpha$ expression levels between groups (resistant and susceptible to $\mathrm{H}$. contortus infection) depending on the reference gene used have demonstrated that inappropriate reference gene selection can lead to misinterpretation of gene expression results. This fact is due to high expression variations in a non-stable reference gene being transferred to the target-gene, which can lead to under- or over-estimation of the relative quantification data and important changes in statistical significance, corroborating the findings of other studies [20, 33, 34, 45].

\section{Conclusion}

The geometric mean of GAPDH and YWHAZ demonstrated the highest stability in abomasal fundic region and abomasal lymph nodes of Morada Nova sheep resistant and susceptible to $H$. contortus infection, whereas $Y W H A Z$ was the most stable reference gene in the abomasal pyloric region. G6PDH, in turn, was listed as the least stable gene by the three computational programs. More importantly, performing stability testing from a selection of candidate genes, based on different programs, is essential in order to avoid misinterpretation of relative gene expression results.

Acknowledgements The present study was funded by Fundação de Amparo à Pesquisa do Estado de São Paulo (FAPESP), through a research grant (Grant No. 2017/01626-1) and scholarships (Grant Nos. 2017/00373-2 and 2017/24289-0), and scholarships from Conselho Nacional de Desenvolvimento Científico e Tecnológico (PIBIC/ CNPq, Grant Nos. 122027/2017-5 and 118297/2015-5).

\section{Compliance with ethical standards}

Conflict of interest The authors declare that they have no conflict of interest.

Ethical approval All procedures were approved by the Embrapa Pecuária Sudeste Ethics Committee on Animal Experimentation (process no. 04/2017), in accordance with the ethical principles and guidelines for animal experimentation adopted by the Brazilian College of Experimentation.

\section{References}

1. Amarante AFT, Bricarello PA, Rocha RA, Gennari SM (2004) Resistance of Santa Ines, Suffolk and Ile de France sheep to 
naturally acquired gastrointestinal nematode infections. Vet Parasitol 120:91-106. https://doi.org/10.1016/j.vetpar.2003.12

2. Cavalcante ACR, Vieira LS, Chagas ACS, Molento MB (2009) Doenças parasitárias de caprinos e ovinos: epidemiologia e controle. Embrapa Informação Tecnológica, Brasilia

3. Chagas AC, Katiki LM, Silva IC, Giglioti R, Esteves SN, Oliveira MC, Barioni Júnior W (2013) Haemonchus contortus: a multipleresistant Brazilian isolate and the costs for its characterization and maintenance for research use. Parasitol Int 62:1-6. https://doi. org/10.1016/j.parint.2012.07.001

4. Almeida FA, Garcia KC, Torgerson PR, Amarante AF (2010) Multiple resistance to anthelmintics by Haemonchus contortus and Trichostrongylus colubriformis in sheep in Brazil. Parasitol Int 59:622-625. https://doi.org/10.1016/j.parint.2010.09.006

5. Cintra MC, Teixeira VN, Nascimento LV, Sotomaior CS (2016) Lack of efficacy of monepantel against Trichostrongylus colubriformis in sheep in Brazil. Vet Parasitol 216:4-6. https://doi. org/10.1016/j.vetpar.2015.11.013

6. Facó O, Paiva SR, Alves LRN, Lobo RNB, Vilela LCV (2008) Raça Morada Nova: origem, características e perspectivas. Embrapa Caprinos, Sobral

7. McManus C, Hermuche P, Paiva SR, Moraes JCF, Melo CB, Mendes C (2014) Geographical distribution of sheep breeds in Brazil and their relationship with climatic and environmental factors as risk classification for conservation. Braz $\mathrm{J}$ Sci Technol 1:2-15. https://doi.org/10.1186/2196-288X-1-3

8. Issakowicz J, Issakowicz ACKS, Bueno MS, Costa RLD, Katiki LM, Torres Geraldo A, Abdalla AL, Mcmanus C, Louvandini H (2016) Parasitic infection, reproductive and productive performance from Santa Inês and Morada Nova ewes. Small Rumin Res 136:96-103. https://doi.org/10.1016/j.smallrumres.2016.01.015

9. Ferreira JB, Bezerra ACDS, Guilhermino MM, Leite JHGM et al (2017) Performance, endoparasitary control and blood values of ewes locally adapted in semiarid region. Comp Immunol Microbiol Infect Dis 52:23-29. https://doi.org/10.1016/j.cimid .2017.05.004

10. Zaros LG, Bricarello PA, Amarante AFT, Coutinho LL (2007) Quantification of bovine cytokine expression using real-time RT-PCR methodology. Genet Mol Biol 30:575-579. https://doi. org/10.1590/S1415-47572007000400012

11. Wang W, Yuan C, Wang S, Song X, Xu L, Yan R, Hasson IA, Li $X$ (2014) Transcriptional and proteomic analysis reveal recombinant galectins of Haemonchus contortus down-regulated functions of goat PBMC and modulation of several signaling cascades in vitro. J Proteomics 98:123-137. https://doi.org/10.1016/j.jprot .2013.12.017

12. MacKinnon KM, Bowdridge SA, Kanevsky-Mullarky I, Zajac AM, Notter DR (2015) Gene expression profiles of hair and wool sheep reveal importance of Th2 immune mechanisms for increased resistance to Haemonchus contortus. J Anim Sci 93:2074-2082. https://doi.org/10.2527/jas.2014-8652

13. Patra G, Jas R, Ghosh J, Borthakur SK, Paul A (2016) Single nucleotide polymorphism and expression studies of the interferon gamma gene and its role against Haemonchus contortus in Garole and Sahabadi sheep. Asian Pac J Trop Dis 6:106-112. https://doi. org/10.1016/S2222-1808(15)60994-X

14. Bustin SA, Benes V, Garson JA, Hellemans J, Huggett J, Kubista $M$ et al (2009) The MIQE guidelines: minimum information for publication of quantitative real-time PCR experiments. Clin Chem 55:611-622. https://doi.org/10.1373/clinchem.2008.112797

15. De Spiegelaere W, Dern-Wieloch J, Weigel R, Schumacher V, Schorle H, Nettersheim D et al (2015) Reference gene validation for RT-qPCR, a note on different available software packages. PLoS ONE. https://doi.org/10.1371/journal.pone.0122515

16. Guo Z, González JF, Hernandez JN, McNeilly TN et al (2016) Possible mechanisms of host resistance to Haemonchus contortus infection in sheep breeds native to the Canary Islands. Sci Rep 1:1-14. https://doi.org/10.1038/srep26200

17. Bustin SA (2000) Absolute quantification of mRNA using realtime reverse transcription polymerase chain reaction assays. J Mol Endocrinol 25:169-193. https://doi.org/10.1677/jme.0.0250169

18. Bustin SA, Benes V, Nolan T, Pfaffl MW (2005) Quantitative real-time RT-PCR - a perspective. J Mol Endocrinol 34:597-601. https://doi.org/10.1677/jme.1.01755

19. Wong ML, Medrano JF (2005) Real-time PCR for mRNA quantitation. Biotechniques 39:75-85. https://doi.org/10.2144/05391 RV01

20. Thomas KC, Zheng XF, Garces Suarez F, Raftery JM, Quinlan KGR, Yang N et al (2014) Evidence based selection of commonly used RT-qPCR reference genes for the analysis of mouse skeletal muscle. PLoS ONE. https://doi.org/10.1371/journal.pone.00886 53

21. Vandesompele J, De Preter K, Pattyn F, Poppe B, Van Roy N, De Paepe A, Speleman F (2002) Accurate normalization of realtime quantitative RT-PCR data by geometric averaging of multiple internal control genes. Genome Biol. https://doi.org/10.1186/gb2002-3-7-research0034

22. Radonić A, Thulke S, Mackay IM, Landt O, Siegert W, Nitsche A (2004) Guideline to reference gene selection for quantitative realtime PCR. Biochem Biophys Res Commun 313:856-862. https:// doi.org/10.1016/j.bbrc.2003.11.177

23. Paolacci AR, Tanzarella OA, Porceddu E, Ciaffi M (2009) Identification and validation of reference genes for quantitative RT-PCR normalization in wheat. BMC Mol Biol. https://doi. org/10.1186/1471-2199-10-11

24. Gentile AM, Lhamyani S, Coin-Araguez L, Oliva-Olivera W, Zayed H, Vega-Rioja A, Monteseirin J, Romero-Zerbo SY, Tinahones FJ, Bermudez-Silva FJ, El Bekay R (2016) RPL13A and EEF1A1 are suitable reference genes for qPCR during adipocyte differentiation of vascular stromal cells from patients with different BMI and HOMA-IR. PLoS ONE. https://doi.org/10.1371/ journal.pone. 0157002

25. Ofinran O, Bose U, Hay D, Abdul S, Tufatelli C, Khan R (2016) Selection of suitable reference genes for gene expression studies in normal human ovarian tissues, borderline ovarian tumours and ovarian cancer. Mol Med Rep 14:5725-5731. https://doi. org/10.3892/mmr.2016.5933

26. Xiao J, Li X, Liu J, Fan X, Lei H, Li C (2017) Identification of reference genes in blood before and after entering the plateau for SYBR green RT-qPCR studies. PeerJ. https://doi.org/10.7717/ peerj. 3726

27. Pfaffl MW, Tichopad A, Prgomet C, Neuvians TP (2004) Determination of stable housekeeping genes, differentially regulated target genes and sample integrity: BestKeeper-Excel-based tool using pair-wise correlations. Biotechnol Lett 26:509-515. https:// doi.org/10.1023/B:BILE.0000019559.84305.47

28. Andersen CL, Jensen JL, Ørntoft TF (2004) Normalization of realtime quantitative reverse transcription-PCR data: a model-based variance estimation approach to identify genes suited for normalization, applied to bladder and colon cancer data sets. Cancer Res 64:5245-5250. https://doi.org/10.1158/0008-5472.CAN-04-0496

29. Wood IB, Amaral NK, Bairden K et al (1995) World Association for the Advancement of Veterinary Parasitology (W.A.A.V.P.) second edition of guidelines for evaluating the efficacy of anthelmintics in ruminants (bovine, ovine, caprine). Vet Parasitol 58:181-213. https://doi.org/10.1016/0304-4017(95)00806-2

30. Garcia-Crespo D, Juste RA, Hurtado A (2005) Selection of ovine housekeeping genes for normalisation by real-time RT-PCR; analysis of PrP gene expression and genetic susceptibility to scrapie. BMC Vet Res. https://doi.org/10.1186/1746-6148-1-3

31. Zaros LG, Coutinho LL, Sider LH, Medeiros HR, Neves MR et al (2010) Evaluation of reference genes for real-time PCR studies of 
Brazilian Somalis sheep infected by gastrointestinal nematodes. Genet Mol Biol 33:486-490. https://doi.org/10.1590/S1415 $-47572010000300018$

32. Vorachek WR, Bobe G, Hall JA (2013) Reference gene selection for quantitative PCR studies in sheep neutrophils. Int J Mol Sci 14:11484-11495. https://doi.org/10.3390/ijms140611484

33. Zhu W, Lin Y, Liao H, Wang Y (2015) Selection of reference genes for gene expression studies related to intramuscular fat deposition in Capra hircus skeletal muscle. PLoS One. https:// doi.org/10.1371/journal.pone.0121280

34. Pereira-Fantini PM, Rajapaksa AE, Oakley R, Tingay DG (2016) Selection of reference genes for gene expression studies related to lung injury in a preterm lamb model. Sci Rep. https://doi. org/10.1038/srep26476

35. Hassan M, Hanrahan JP, Good B, Mulcahy G, Sweeney T (2011) A differential interplay between the expression of Th1/ Th2/Treg related cytokine genes in Teladorsagia circumcincta infected DRB1*1101 carrier lambs. Vet Res. https://doi. org/10.1186/1297-9716-42-45

36. Pfaffl MW (2001) A new mathematical model for relative quantification in real-time RT-PCR. Nucleic Acids Res. https://doi. org/10.1093/nar/29.9.e45

37. Giulietti A, Overbergh L, Valckx D, Dacallonne B, Bouillon R, Mathieu C (2001) An overview of real time quantitative PCR: applications to quantify cytokine gene expression. Methods 25:386-401. https://doi.org/10.1006/meth.2001.1261

38. Cao H, Kabaroff LC, You Q, Rodrigues A, Boermans H, Karrow NA (2006) Characterization of ovine hepatic gene expression profiles in response to $E$. coli lipopolysaccharide using a bovine cDNA microarray. BMC Vet Res. https://doi. org/10.1186/1746-6148-2-34
39. Gossner AG, Venturina VM, Shaw DJ, Pemberton JM, Hopkins J (2012) Relationship between susceptibility of Blackface sheep to Teladorsagia circumcincta infection and an inflammatory mucosal T cell response. Vet Res. https://doi.org/10.1186/1297-9716-43-26

40. Zaros LG, Bricarello PA, Amarante AF, Rocha RA, Kooyman FN, De Vries E, Coutinho LL (2010) Cytokine gene expression in response to Haemonchus placei infections in Nelore cattle. Vet Parasitol 171:68-73. https://doi.org/10.1016/j.vetpar.2010.03.020

41. Gossner A, Wikie H, Jodhi A, Hopkins J (2013) Exploring the abomasal lymph node transcriptome for genes associated with resistance to the sheep nematode Teladorsagia circumcincta. Vet Res. https://doi.org/10.1186/1297-9716-44-68

42. Peletto S, Bertuzzi S, Campanella C et al (2011) Evaluation of internal reference genes for quantitative expression analysis by real-time PCR in ovine whole blood. Int J Mol Sci 12:7732-7747. https://doi.org/10.3390/ijms12117732

43. Schulze F, Malhan D, El Khassawna T et al (2017) A tissue-based approach to selection of reference genes for quantitative real-time PCR in a sheep osteoporosis model. BMC Genomics. https://doi. org/10.1186/s12864-017-4356-4

44. Mo F, Zhao J, Liu N, Cao L, Jiang S (2014) Validation of reference genes for RT-qPCR analysis of CYP4T expression in crucian carp. Genet Mol Biol 37:500-507. https://doi.org/10.1590/S1415 $-47572014000400005$

45. Sellars MJ, Vuocolo T, Leeton LA, Coman GJ, Degnan BM, Preston NP (2007) Realtime RT-PCR quantification of Kuruma shrimp transcripts: a comparison of relative and absolute quantification procedures. J Biotechnol 129:391-399. https://doi.org/10.1016/j. jbiotec.2007.01.029 